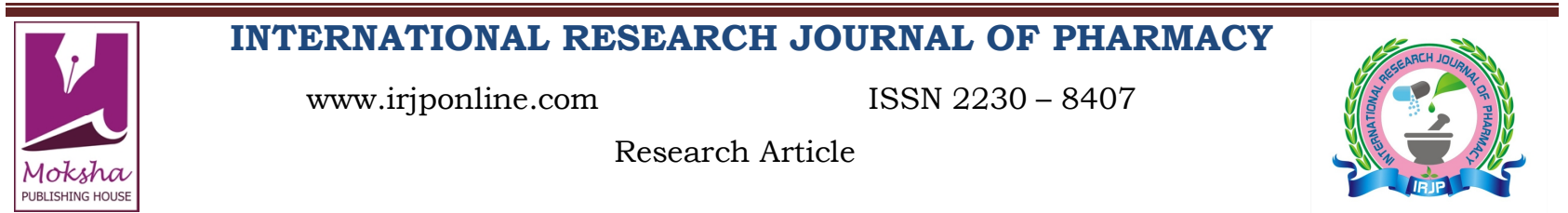

\section{STUDY OF SERUM URIC ACID IN CHRONIC LIVER DISEASE AND ITS RELATION WITH OTHER PARAMETERS}

Rudrajit Paul ${ }^{1}$, Hridish N Chakravarti ${ }^{1}$, Sanjay K Mandal ${ }^{2}$, Sumanta Chatterjee ${ }^{3}$, Partha S Choudhury ${ }^{3}$

${ }^{1}$ Assistant Professor, Department of Medicine, Medical College, Kolkata, West Bengal, India

${ }^{2}$ Associate Professor, Department of Medicine, Medical College, Kolkata, West Bengal, India

${ }^{3}$ Resident, Department of Medicine, Medical College, Kolkata, West Bengal, India

*Corresponding Author Email: docr89@gmail.com

Article Received on: 20/05/13 Revised on: 01/06/13 Approved for publication: 14/07/13

DOI: 10.7897/2230-8407.04736

IRJP is an official publication of Moksha Publishing House. Website: www.mokshaph.com

(C) All rights reserved.

\section{ABSTRACT}

In chronic liver disease, high uric acid levels are independently associated with severe disease and poor prognosis. However, studies regarding the relation of uric acid levels with different parameters of liver dysfunction are rare from India. Our aim was to study uric acid (UA) levels in chronic liver disease and find any association of UA with different blood parameters and prognosis. We selected patients of chronic liver disease of any etiology. We did the serum UA test along with full liver function tests. Child Turcot Pugh (CTP) score was calculated for each patient. Then by suitable statistical tests, any association or correlation was studied. We had total of 52 patients with $31 \%$ female. 19 (36.5\%) of the cases had liver disease secondary to alcoholism followed by 15 cases of non alcoholic fatty liver disease. $69.2 \%$ of the patients were in CTP class B or C. Serum UA levels were significantly higher in chronic viral hepatitis cases $(\mathrm{p}<0.001)$. UA levels showed significant correlation with serum bilirubin $(\mathrm{r}=0.567)$, SGOT $(\mathrm{r}=0.464)$ and mortality. The UA levels showed significant correlation with severe disease and mortality. However, whether UA can be included in risk stratification of chronic liver disease can only be determined by larger randomized trials.

Keywords: Cirrhosis, Uric Acid, NAFLD, Child Turcot Pugh score, inflammation.

\section{INTRODUCTION}

Uric acid (UA) is the end product of purine metabolism ${ }^{1}$. It is produced in conditions where there is cellular destruction and thus, degradation of the nuclear material. Uric acid is not only a byproduct of cell death, but recent research has discovered that it is a mediator of inflammation and tissue damage ${ }^{2}$. Uric acid in tissues may be a major activator of inflammosomes and thus, it promotes damage to surrounding tissues $^{3}$. In chronic liver disease, there is progressive damage to liver parenchyma with subsequent loss of function. In chronic liver disease of different etiologies, uric acid levels are found to be high. In cases of non alcoholic fatty liver disease (NAFLD), high uric acid levels are considered as independent etiological risk factors ${ }^{4}$. Also, a high uric acid level is known effect of alcohol metabolism and thus, hyperuricemia may be found in alcoholic liver disease $\mathrm{e}^{5,6}$. In different biological studies, UA levels have been found to correlate directly with the level of tissue damage ${ }^{7}$. Compared to the serum levels, the tissue levels of UA may be even better predictors of tissue injury ${ }^{7}$. Thus, UA may be considered as a marker of tissue damage. We therefore undertook this pilot study to find the level of uric acid in patients of chronic liver disease and its correlation, if any, with etiology and other parameters.

\section{Aim and Objectives}

1. To measure the uric acid levels in chronic liver disease (CLD) patients

2. To study for any correlation of UA levels with different biochemical parameters and outcome

\section{Patients and methods}

This was a hospital based cross sectional, observational study. We selected patients of CLD of any etiology, coming to the outdoor or indoors of the Department of Medicine of our tertiary institution. After proper history and clinical examination the patients were included for the study. Patients of known malignancy, patients on chemotherapy, patients on allopurinol / feboxostat / thiazides / frusemide, patients with known infections and patients of recent surgery / trauma were excluded from the study. The chronic liver disease diagnosis was confirmed by liver biopsy. We measured the serum uric acid levels in all patients, along with full liver function tests including serum bilirubin, enzymes, protein levels and prothrombin time. For diagnosis of NAFLD, serum insulin levels (fasting) were measured along with blood glucose. Based on clinical tests and laboratory values, Child Turcot Pugh (CTP) score was done for each patient. Indoor patients were followed up till discharge or death and outdoor patients were followed up for 6 months for subsequent course of illness. The data was arranged in Microsoft Excel worksheet (Redmond, WA). Continuous variables are expressed as mean \pm S.D. Discrete variables are expressed as percentages. 2 tailed Student's T Test was used to find the significance of difference between variables. Chi square test / Fisher's exact test is used in discrete variables and contingency tables. For non parametric variables, Mann Whitney U Test was done. Correlation was calculated by Pearson's coefficient. For calculations we used online free software like GraphPad, MedCalc. $\mathrm{P}$ value $<0.05$ is considered significant.

\section{RESULTS}

We had a total of 52 patients in our study. As Table 1 shows, $16(30.8 \%)$ of our patients were female and $51.9 \%$ were from rural background. Of the different etiologies of CLD, alcoholic was the commonest $(36.5 \%$; $n=19)$ followed by NAFLD $(n=15)$. We got 2 cases of autoimmune hepatitis, both of whom were female. 4 cases of CLD (7.7 \%) were of unknown cause (cryptogenic). 36 (69.2\%) of the patients presented in CTP class B or C. however, $29(80.5 \%)$ of male patients were in CTP classes B or C whereas 7 (43.7\%) of the female patients were in those classes $(p=0.0202$ by 
Rudrajit Paul et al. Int. Res. J. Pharm. 2013, 4 (7)

Fisher's Exact test, 2 tailed). Among male patients, $50 \%$ were alcoholic, while among females, $43.7 \%$ had NASH as cause of CLD. Altogether $19.2 \%(n=10)$ of our patients died.

Table 1: Table showing the general characteristics of the patients

\begin{tabular}{|c|c|c|c|c|}
\hline \multicolumn{2}{|c|}{ Parameter } & Male & Female & Total \\
\hline \multirow[t]{2}{*}{ Residence } & Rural & 21 & 6 & 27 \\
\hline & Urban & 15 & 10 & 25 \\
\hline \multirow[t]{6}{*}{ Etiology } & Alcoholic & 18 & 1 & 19 \\
\hline & Chronic viral hepatitis & 6 & 5 & 11 \\
\hline & Autoimmune hepatitis & 0 & 2 & 2 \\
\hline & Cryptogenic & 3 & 1 & 4 \\
\hline & Wilson's disease & 1 & 0 & 1 \\
\hline & NASH & 8 & 7 & 15 \\
\hline \multirow[t]{3}{*}{ CTP class } & $\mathrm{A}$ & 7 & 9 & 16 \\
\hline & $\mathrm{B}$ & 23 & 6 & 29 \\
\hline & $\mathrm{C}$ & 6 & 1 & 7 \\
\hline \multirow{3}{*}{$\begin{array}{l}\text { Ultimate } \\
\text { fate }\end{array}$} & Improved & 12 & 8 & 20 \\
\hline & Remained same & 16 & 6 & 22 \\
\hline & Died & 8 & 2 & 10 \\
\hline
\end{tabular}

Table 2: Table showing the uric acid levels in various subsets of patients

\begin{tabular}{|c|c|c|}
\hline Parameter & & Uric acid levels (mg/dL) \\
\hline \multirow{4}{*}{ Etiology } & Alcoholic & $4.62 \pm 1.7$ \\
\cline { 2 - 3 } & Chronic viral hepatitis & $8.51 \pm 2.7$ \\
\cline { 2 - 3 } & Autoimmune hepatitis & $8.8 \pm 0.56$ \\
\cline { 2 - 3 } & Cryptogenic & $3.85 \pm 0.98$ \\
\cline { 2 - 3 } & Wilson's disease $(\mathrm{n}=1)$ & 5.6 \\
\cline { 2 - 3 } & NAFLD $(\mathrm{n}=15)$ & $5.87 \pm 1.74$ \\
\hline CTP class & $\mathrm{A}$ & $3.98 \pm 1.3$ \\
\cline { 2 - 3 } & $\mathrm{B}$ & $5.74 \pm 2.35$ \\
\cline { 2 - 3 } & $\mathrm{C}$ & $9.38 \pm 2.31$ \\
\hline Ultimate fate & Improved & $5.43 \pm 2.14$ \\
\cline { 2 - 3 } & Remained same & $4.22 \pm 1.4$ \\
\cline { 2 - 3 } & Died & $9.57 \pm 2.23$ \\
\cline { 2 - 3 } & \multicolumn{2}{|c}{} \\
\hline
\end{tabular}

Table 3: Table showing the correlation of uric acid with various parameters

\begin{tabular}{|c|c|c|}
\hline Parameter & Correlation coefficient & P value \\
\hline Total bilirubin & 0.567 & 0.0002 \\
\hline SGOT & 0.464 & 0.0033 \\
\hline SGPT & -0.111 & 0.5 \\
\hline ALP & 0.18 & 0.27 \\
\hline Albumin & -0.43 & 0.007 \\
\hline INR & 0.77 & $<0.0001$ \\
\hline Total count & 0.77 & $<0.0001$ \\
\hline CTP score & 0.44 & 0.02 \\
\hline Age & 0.07 & 0.67 \\
\hline
\end{tabular}

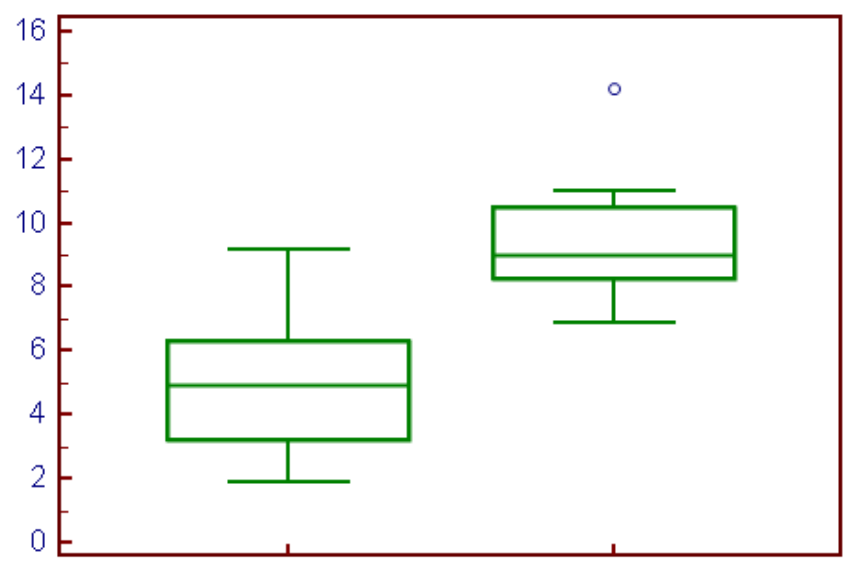

uric acid in survivors uric acid in those who died

Figure 1: box and whisker plot showing uric acid levels based on mortality [uric acid in Y-axis in mg/dl]

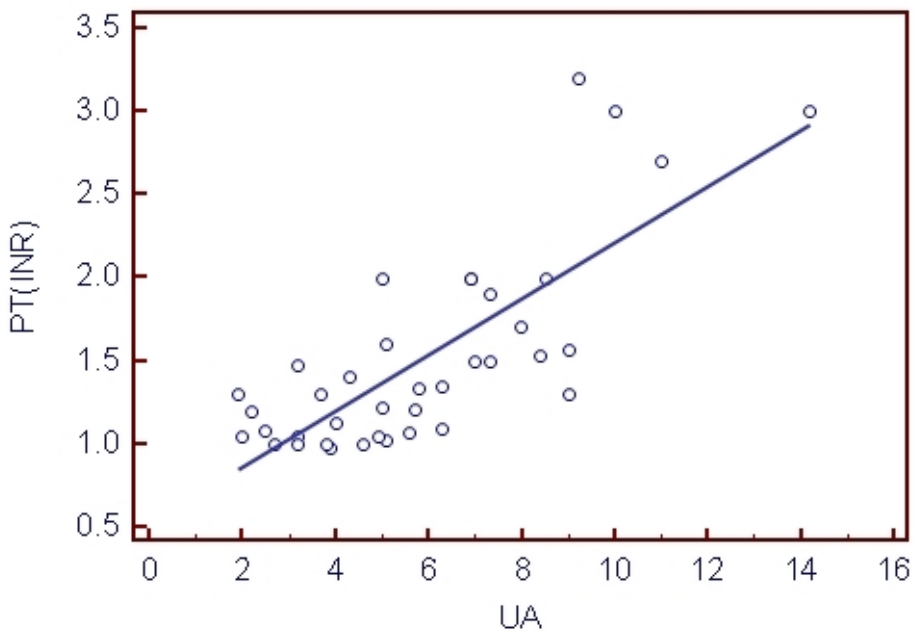

Figure 2: x-y scatter diagram showing correlation of serum uric acid with INR 
Table 2 shows the UA levels in various subsets of our patients. Student's t test between uric acid levels in viral hepatitis and chronic alcoholic liver disease cases show the viral hepatitis induced CLD had significantly higher UA levels $(\mathrm{p}<0.0001)$. The number of cases in other etiologies is too small for statistical tests. Also, UA levels were significantly higher in CTP classes $\mathrm{B}$ and $\mathrm{C}$ as compared to CTP class A $(p<0.0001)$. Also, considering UA values in CTP classes B and C together $(6.72 \pm 2.82)$, the values in CTP class A are significantly less $(3.98 \pm 1.3$; $\mathrm{p}=0.0029)$. In patients who died, the UA levels were significantly higher compared to the survivors ( $\mathrm{p}=0.0002$; Mann Whitney test; Figure 1). Table 3 shows the correlation data of serum UA with some selected parameters, both clinical and laboratory related. It is seen that UA has strong correlation with both serum bilirubin and SGOT $(r=0.567$ and 0.464 respectively; $\mathrm{p}<0.05$ ). Also, UA showed significant positive correlation with INR and total leukocyte count. The correlation between UA and INR is shown in Figure 2.

\section{DISCUSSION}

In our observational cross sectional study, we found significantly high serum UA levels in certain cases of CLD like chronic viral hepatitis. UA levels were higher with higher CTP scores and also it was linked to mortality. Serum UA values showed significant correlation with some parameters of liver function. Elevated UA levels reflect oxidative stress in the tissues. It is also a marker of metabolic syndrome. Both these conditions are associated with progression of chronic liver disease ${ }^{8}$. A study from United States found that patients with high serum uric acid had higher risk of cirrhosis-related hospitalization or death ${ }^{8}$. Also, a higher uric acid was related to elevation of different liver enzymes. In our study, we found that higher serum UA correlated with higher CTP grading and mortality (Table 2). However, for actual relation of UA with mortality we need follow up data to plot survival curves. A study from china also found that hyperuricemia is related significantly with risk of NAFLD ${ }^{4}$. In our study, we found significantly high UA levels in CLD due to viral hepatitis and autoimmune hepatitis (Table 2). Our study did not find high UA levels in NAFLD cases. However, hyperuricemia is a marker of insulin resistance and thus, NAFLD is likely in this patient group as a complication of metabolic syndrome ${ }^{8}$. We found high UA levels in chronic viral hepatitis $(8.51 \pm 2.7 \mathrm{mg} / \mathrm{dl})$. A study from Italy has found that high UA levels are associated with poor outcome in chronic viral hepatitis ${ }^{9}$. This may be because high UA indicates ongoing hepatocellular destruction. So far, most of the studies on serum UA have been done with NAFLD ${ }^{10}$. In one prospective study from China, they found that hyperuricemia was an independent predictor of development of NAFLD with hazard ratio of $1.62^{10}$. However, whether this actually indicates a pathogenic variable or just an epiphenomenon is still doubtful. Another Korean study showed that UA is correlated with serum hsCRP in NAFLD ${ }^{11}$. This may indicate an evidence of the role of UA in inflammatory cascade. A 30 year old study on acute fatty liver of pregnancy found universally high Serum $\mathrm{UA}^{12}$. But the exact pathogenic role has never been discussed. In our study, we found significant correlation of serum UA with some parameters of liver function like bilirubin, SGOT and INR. The relation between UA and these parameters has not been well studies previously. A study showed significant correlation of UA levels with degree of hepatic histological change ${ }^{11}$. Another study from
Greece also showed increasing UA with increasing hepatic enzymes in metabolic syndrome ${ }^{13}$. But whether lowering of the uric acid can halt the disease or prevent future hepatic or cardiac morbidity is unknown ${ }^{13}$. Another Korean study also found significant relation of serum UA with liver histology grades $^{14}$. We found higher UA levels in patients with higher CTP grades. Although we could not find any study linking UA with CTP grades, an Indian study has shown higher blood oxidative markers with higher CTP grades ${ }^{15}$. UA is also considered an oxidative marker for liver damage. Our study is limited by the small number of patients, lack of histology data and cross sectional nature of the study. Serum UA was measured only once in the course of CLD. Still this small study shows significant correlations of UA with various parameters of liver dysfunction.

\section{CONCLUSION}

Studies regarding serum UA in CLD are still scanty. Serum UA may be considered as a marker of severity of CLD. The levels are found to correlate with higher CTP grades. It may thus act as a surrogate marker in assessing prognosis of CLD, especially in viral hepatitis and autoimmune hepatitis where there is increased cellular destruction. The evidence is mostly for NAFLD cases. However, a larger prospective case control study is needed to find the exact role of UA in risk stratification of CLD cases.

\section{ACKNOWLEDGEMENT}

The principal and MSVP, Medical College Kolkata, India for allowing us to conduct this study

\section{REFERENCES}

1. Burns CM, Wortmann RL. Disorders of Purine and Pyrimidine metabolism. In Longo DL, Kasper DL, Jameson JL, Fauci AS, Hauser SL, Loscalzo J (Eds.). Harrison's Principles of Internal Medicine. $18^{\text {th }}$ ed. USA: The McGraw-Hill Companies, Inc.; 2011. p. 3181-7

2. Kono H, Jen Chen C, Ontiveros F, Rock KL. Uric acid promotes an acute inflammatory response to sterile cell death in mice. J Clin Invest 2010; 120: 1939. http://dx.doi.org/10.1172/JCI40124 PMid:20501947 PMCid:PMC2877935

3. Gasse P, Riteau N, Charron S, Girre S, Fick L, Pétrilli V et al. Uric acid is a danger signal activating NALP3 inflammasome in lung injury inflammation and fibrosis. Am J Respir Crit Care Med 2009; 179: 90313. http://dx.doi.org/10.1164/rccm.200808-1274OC PMid: 19218193

4. $\mathrm{Li} \mathrm{Y,} \mathrm{Xu} \mathrm{C,} \mathrm{Yu} \mathrm{C,} \mathrm{Xu} \mathrm{L,} \mathrm{Miao} \mathrm{M.} \mathrm{Association} \mathrm{of} \mathrm{serum} \mathrm{uric} \mathrm{acid} \mathrm{level}$ with non-alcoholic fatty liver disease: a cross-sectional study. J Hepatol 2009; 50: 1029-34. http://dx.doi.org/10.1016/j.jhep.2008.11.021 PMid:19299029

5. Takase S, Takada A, Tsutsumi M, Matsuda Y. Biochemical markers of chronic alcoholism. Alcohol 1985; 2: 405-10. http://dx.doi.org/10.1016 /0741-8329(85)90104-1

6. Yamamoto T, Moriwaki Y, Takahashi S. Effect of ethanol on metabolism of purine bases (hypoxanthine, xanthine and uric acid). Clin Chim Acta 2005; 356: 35-57. http://dx.doi.org/10.1016/ j.ccen.2005.01.024 PMid: 15936302

7. Kanemitsu H, Tamura A, Sano K, Iwamoto T, Yoshiura M, Iriyama K. Changes of uric acid level in rat brain after focal ischemia. J Neurochem 1986; 46: 851-3. http://dx.doi.org/10.1111/j.14714159.1986.tb13049.x PMid:3950611

8. Afzali A, Weiss NS, Boyko EJ, Ioannau GN. Association between serum uric acid level and chronic liver disease in the United States. Hepatology 2010; 52: 578-9. http://dx.doi.org/10.1002/hep.23717 PMid:20683957

9. Pellicano R, Puglisi G, Ciancio A, Balzola F, Saracco G, Ciccone G et al. Is serum uric acid a predictive factor of response to IFN-treatment in patients with chronic hepatitis C infection? J Med Virol 2008; 80: 62831. http://dx.doi.org/10.1002/jmv.21123 PMid:18297716

10. Xu C, Yu C, Xu L, Miao M, Li Y. High Serum Uric Acid Increases the Risk for Nonalcoholic Fatty Liver Disease: A Prospective Observational Study. PLoS ONE 5(7): e11578. http://dx.doi.org/10.1371 /journal.pone.0011578 [Cited 2013 May 15]

11. Lee YJ, Lee HR, Lee JH, Shin YH, Shim JY. Association between serum uric acid and non-alcoholic fatty liver disease in Korean adults. 
Clin Chem Lab Med 2010; 48: 175-80. http://dx.doi.org/10.1515/ cclm.2010.037 PMid:19961393

12. Burroughs AK, Seong NH, Dojcinov DM, Scheuer PJ, Sherlock SV. Idiopathic acute fatty liver of pregnancy in 12 patients. Q J Med 1982; 51(204): 481-97. PMid:7156326

13. Angelos E, Natalia GV, Demosthenes P, Aikaterini G, Georgios Z, Evangelos $\mathrm{V}$ et al. The Association between Uric Acid and Hepatic Function Markers with the Metabolic Syndrome in Middle-aged, Overweight and Obese People. The Endocrinologist 2012; 20: 312-5.

14. Lee K. Relationship between uric acid and hepatic steatosis among Koreans. Diabetes Metab 2009; 35: 447-51. http://dx.doi.org/10.1016 /j.diabet.2009.04.011 PMid:19879789
15. Bhandari S, Agarwal MP, Dwivedi S, Banerjee BD. Monitoring oxidative stress across worsening child pugh class of cirrhosis. Indian $\mathrm{j}$ Med Sci 2008; 62: 44-51. http://dx.doi.org/10.4103/0019-5359.48456

\section{Cite this article as:}

Rudrajit Paul, Hridish N Chakravarti, Sanjay K Mandal, Sumanta Chatterjee, Partha S Choudhury. Study of serum uric acid in chronic liver disease and its relation with other parameters. Int. Res. J. Pharm. 2013; 4(7):162-165 http://dx.doi.org/10.7897/2230-8407.04736 